\title{
FENOMENOLOGIA TOMIZUJĄCA W KSIĄŻCE „OSOBA I CZYN” *
}

Książka Osoba i czyn - jak czytamy na cytowanej tutaj kilka razy stronie 22 - jest próbą scalenia dwóch filozofii: filozofii bytu i filozofii świadomości. Jest terenem spotkania, i to nie przypadkowego i nie zewnętrznego, tomizmu i fenomenologii. Jest książką z zakresu filozofii człowieka. Wbrew cytowanej tutaj opinii prof. Kalinowskiego uważam, że jest to jednak książka z zakresu filozofii człowieka. I prezentowaną w niej orientację można scharakteryzować jako - powiedziałbym fenomenologię tomizującą. Dlaczego?

Dlatego, że właściwie mamy tutaj do czynienia $z$ pewnym opisem tego, co bezpośrednio dane; opisem, który w zasadniczym kształcie, chociaż ujęty jest jakoś teoretycznie - miejscami abstrakcyjnie - w zasadniczym kształcie nie wychodzi poza sens tego, co bezpośrednio dane. Niemniej jednak w pewnych sformułowaniach opis ten jest uzupełniony przez teorię skądinąd wziętą; np. na stronach 40, 52, 62, są sformułowania, w których przekracza się opis fenomenologiczny. Przekracza się kierując się pewną teorią, która jest teorią metafizyki tomistycznej. Tak, że zasadniczo jest to fenomenologia, mimo że podprowadzona pod pewną metafizykę, co więcej, w niektórych sformułowaniach korzystająca chociaż to explicite nie zawsze się zaznacza $-\mathrm{z}$ pewnych schematów pojęciowych wziętych z metafizyki tomistycznej. Z tego powodu okreŚliłbym tę książkę jako książkę z zakresu fenomenologii tomizującej.

W książce tej znajdujemy zarysowaną — w sposób ożywiający i unaoczniający pewne stare intuicje - strukturę osoby. Myślę, że to, co jest pokazane, jest pokazane $\mathrm{z}$ intencją opisową. Partie szczególnie jakoś owocne i szczególnie pobudzające czytelnika to opisanie spotkania w czło-

* Tekst pochodzi z zapisu magnetofonowego i stąd zachował pewne w’aściwości stylistyczne głosu w dyskusji. 
wieku podmiotowości i sprawczości, scalenia się w wewnętrznej strukturze w jedność różnorodnych elementów i aspektów. Czytamy na s. 95, że „»człowiek« ... jest przede wszystkim jednością życia, a wtórnie tylko i poniekąd ubocznie - jednością przeży c i a". I to jest jakoś częściowo pokazane - to scalanie się potencjalności, świadomości i przedmiotowości, intencjonalności, poznania woli ...

W związku z wypowiedzią jednego z moich przedmówców (Ks. Kłósaka) chciałbym zwrócić uwagę na to, że akt doświadczenia jest tu pojęty, słusznie według mnie, jako czynność zmysłowo-intelektualna, wobec tego podział na czynności zmysłowe i intelektualne w tej koncepcji został zakwestionowany. Każdy akt typu spostrzeżenia ludzkiego jest czynnościa zmysłowo-intelektualną i tradycyjny (ostry) podział między czynnościami zmysłowymi a intelektualnymi do aktu spostrzeżenia ludzkiego nie pasuje. A ostry podział również między poznaniem bezpośrednim a pośrednim nie odpowiada podziałowi na poznanie zmysłowe i intelektualne (bo wydaje mi się, że tutaj te dwa podziały zostały ze sobą jakoś związane). Otóż niekoniecznie to, co jest zmysłowe, jest bezpośrednie, a to, co jest intelektualne, jest pośrednie. Sądzę, że poznanie intelektualne może być zarówno bezpośrednie, jak i pośrednie. Akt spostrzeżenia, ludzki akt doświadczenia jest czynnością zmysłowo-intelektualną i da się scharakteryzować jako poznanie bezpośrednie, a nie jako poznanie pośrednie.

Stąd zupełnie inaczej wyglądałaby sprawa realizmu pośredniego, bezpośredniego itd. - ale to jest dygresja w związku z uwagą Ks. Dziekana Kłósaka. Tak, że ja bym tutaj nie widział problemu w związku z pojęciem doświadczenia w Osobie $i$ czynie. Dla mnie istnieje inny problem, problem z samym pojęciem świadomości! Ja mam po prostu pewne pytania $\mathrm{i}$ po prostu nie umiem sobie odpowiedzieć na te pytania $w$ związku z lekturą Osoby i czynu, a to mi ,przeszkadza" w ustaleniu pewnej podstawy epistemologicznej tego, co znajduję. Bo to, co znajduję i co krótko scharakteryzowałem, uważam że jest po prostu akceptowalne i rozwijalne, po prostu owocne. Natomiast niezależnie od tego pewne sprawy związane z rozdziałem I, które - wydaje mi się - nie są integralnie związane z pozostałymi, nasuwają pewne pytania do dyskusji. Chodzi mi o pojęcie świadomości i o stosunek poznania do wiedzy.

Chociaż pochodzenie tych poglądów dla wielu z Państwa będzie jasne, powiem, jak chciałbym tę rzecz rozumieć i dlaczego, w związku z tym, mam pewne pytania, jeżeli chodzi o Osobę $i$ czyn.

Otóż niewątpliwie termin ,świadomość" jest terminem wieloznacznym i rozróżnijmy tutaj: strumień świadomości, poszczególne przeżycia, akty i stany świadome, i samą świadomość.

Termin ,świadomość" jest terminem niedefiniowalnym, jest terminem 
pierwotnym, którego sens można unaocznić przez jakieś przykłady i porównania. Można jednak wskazać na rozmaite postaci świadomości. Obecnie przypominam podstawowe rozróżnienie fenomenologiczne: rozróżnienie na świadomość aktową i świadomość nie-aktową, na świadomość pozycjonalną i nie-pozycjonalną, intencjonalną i nie-intecjonalną, uprzedmiotowiającą i nie-uprzedmiotowiającą.

Przeżycie aktowe jest intencyjne, tzn. skierowane zawsze na transcendujący je przedmiot, a zarazem jest przeżywane. To znaczy: ujawnia się w strumieniu świadomości jako zachodzące przez sam fakt przeżywania. A więc świadomości ujmowanego przedmiotu towarzyszy świadomość ujmowania przedmiotu, świadomość zachodzenia przeżycia jako ujmowania przedmiotu. I tutaj od razu trzeba rozróżnić te dwie postaci świadomości (bo to tylko w tej chwili będzie nas interesowało). Świadomość przedmiotowo skierowana, aktowo zorganizowana i świadomość polegająca na przeżywaniu, ujawnianiu się samego zachodzenia stanu świadomości.

W związku z tym, że istnieją te dwie zasadnicze postaci świadomości, istnieją również dwie zasadnicze postaci samoświadomości. Tą prostą, elementarną postacią samoświadomości jest przeżywanie: to, że akt świadomości przez samo zachodzenie jakoś się zaznacza w strumieniu świadomości. A oprócz tego — jak wiadomo — w pewnych aktach refleksji (spostrzeżenie immanentne, spostrzeżenie wewnętrzne czy przypomnienie) możemy nasz stan czy akt świadomości uczynić przedmiotem samoświadomości i mamy wtedy do czynienia z samoświadomością refleksyjną. A więc rozróżniamy: świadomość aktową, świadomość nieaktową (tutaj nas interesuje tylko ta postać świadomości nieaktowej, którą nazywamy przeżyciem) i wobec tego przeżycie jako prostą samoświadomość i oprócz tego samoświadomość refleksyjną w postaci spostrzeżenia wewnętrznego, immanentnego czy przypomnienia. To jest taki przyjmowany przeze mnie wiadomej proweniencji model i typologia świadomości i w związku z nim terminologia tutaj stosowana.

Stosunek świadomości do poznania i wiedzy krótko tylko zasygnalizuję. Wiadomo, że poznanie i wiedzę można pojąć różnorodnie. Nie wydaje mi się jednak, żeby można było mówić o nieuświadomionym poznaniu, o nieuświadomionej wiedzy, żebyśmy mogli w dosłownym sensie mówić o wiedzy lub poznaniu nieświadomym. Chyba, żebyśmy uzyskiwanie informacji (bo poznanie tj. przede wszystkim uzyskiwanie informacji) o przedmiocie traktowali jako pewien proces naturalny, polegający na pojawieniu się w podmiocie poznającym pewnej zmiany lub cechy, której rola poznawcza jako czynnika orientacji podmiotu w otoczeniu, jest koniecznie związana z uprzytomnieniem sobie tego czynnika przez podmiot poznania. Tylko przy takim pojęciu poznania, które chyba 
jest „obce” w całej książce Osoba $i$ czyn, można by mówić o tym, że poznanie i świadomość to są rzeczy, które nie muszą w pewnej relacji, nieprzypadkowej, ze sobą pozostawać. W kaźdym razie gdybyśmy takie koncepcje poznania, m. in. na gruncie skrajnego behawioryzmu akceptowali, to byłoby to $\mathrm{z}$ punktu widzenia teorii poznania (to oddzielenie poznania i świadomości) zabiegiem wtórnym, teoretycznym, a nie empirycznie danym. Empirycznie bowiem, w ramach opisu fenomenologicznego, zawsze warunkiem koniecznym poznawania jest przeżywanie czynności poznawania. Dopiero w jakimś zabiegu teoretycznym dochodzi się do takiego modelu poznania, który by oddzielał poznanie od świadomości.

Jak należy wobec tego świadomość rozumieć? - Wydaje mi się, że można świadomość rozumieć albo jako przeżywanie, albo jako refleksję, albo jako samowiedzę. Otóż nie może świadomość być tu pojęta jako refleksja, skoro mówi się niekiedy w książce, że świadomość jest czymś nie-intencjonalnym, czymś co nie uprzedmiotowia. Wszelka refleksja zwraca się do tego, nad czym jest refleksją, mianowicie do swego przedmiotu; ona uprzedmiotawia. Więc jeżeli świadomość nie uprzedmiotawia, nie jest intencjonalna, wobec tego nie może być refleksją; może być przeżywaniem.

Ale gdyby wchodziło tu jednak $w$ grę przeżywanie, to by musiało ono występować razem z tym, czego jest świadomością. Natomiast jeżeli mówi się w książce, że niekiedy świadomość nie musi występować razem z tym, czego jest świadomością, więc nie może ona być traktowana jako przeżycie, bo nie ma tego konstytucyjnego związku przeżywania $\mathrm{z}$ przeżyciem, świadomości zachodzenia przez sam fakt zachodzenia.

Nie jest też samowiedzą. Jej stosunek do samowiedzy jest jakiś szczególny. Mówi się wprawdzie że nie jest świadomość samowiedzą, ale zarazem mówi się, że samowiedza stanowi granicę świadomościowego odzwierciedlenia. Jak moglibyśmy o tym wiedzieć, że samowiedza stanowi granicę świadomościowego odzwierciedlenia, gdy świadomość nie współkonstytuowała samowiedzy?

Wreszcie niekopoi jedna sprawa. Stwierdza się, że świadomość ma charakter intelektualny. Taka uwaga bez komentarza nasuwa pytanie, czy w takim razie z góry odrzuca się świadomość zwierząt?

Otóż to są pytania związane z lekturą Osoby i czynu, które niepokoją $\mathrm{w}$ związku $\mathrm{z}$ rozumieniem koncepcji świadomości. Czy świadomość jest traktowana jako przeżywanie, jako refleksja, jako samowiedza? Ktoś może powiedzieć tak, że te moje pytania wypływają z mojego modelu świadomości, który przedstawiłem krótko poprzednio. Być może, Autor dysponuje innym modelem świadomości. W takim razie narzuca się uwaga, że tutaj czytelnik może czuć się jakoś zagubiony i nie uchwycić tej koncepcji samoświadomości. Problematykę tę sygnalizuję podkreśla- 
jąc, że wszystkie moje zastrzeżenia dotyczące świadomości, jej stosunku do poznania, nie są istotnie związane $z$ pozostałą zawartością Osoby $i$ czynu. I może $\mathrm{z}$ tego jakiś wniosek należałoby wyciągnąć. To znaczy taki wniosek, że po prostu sprawa świadomości jest sprawą osobną dla oceny reszty zawartości książki, w której — jak powiedziałem - pewne sprawy, zwłaszcza związane z koncepcją sumienia, powinności i odpowiedzialności są bardzo intelektualnie intrygujące, i wydaje mi się, bardzo owocne.

P. s. Podczas tej dyskusji zapomniałem zaznaczyć, że w tekstach Osoby $i$ czynu rysuje się mocno jeszcze inna koncepcja świadomości, mianowicie odzwierciedleniowa. Swiadomość jako odzwierciedlenie, odbicie bytu, przedmiotu świadomości. Ale i przyjęcie tej koncepcji jako podstawowej nie usuwa niejednoznaczności w tym względzie Osoby i czynu, a wiedzie ze sobą dodatkowo nowe trudności. Koncepcja świadomości w omawianej książce wymaga rewizji. 